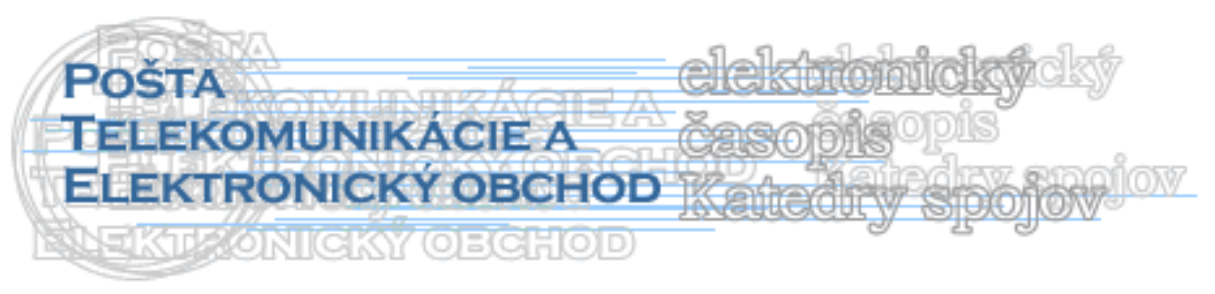

\title{
E-GOVERNMENT V SR
}

\author{
Margita Majerčáková*
}

\section{Úvod}

Informatizácia verejnej správy (e-government) sa zarad’uje medzi kl'účové úlohy programov vlád vyspelých štátov sveta. V rozpočtoch týchto krajín sa v súčasnosti venujú nemalé prostriedky na systematický rozvoj a podporu projektov elektronizácie služieb, ktoré verejná správa každodenne poskytuje občanom štátu. Hlavným ciel’om je zvýšenie kvality služieb a racionalizovanie procesov verejnej správy orientované na poskytovanie služieb. Občan vo vyspelej spoločnosti očakáva od vlády, že úroveň poskytovaných služieb verejnou správou bude porovnatel'ná s najlepšími službami, ktoré poskytuje súkromný sektor. Jedná sa hlavne o faktory presnosti, včasnosti a dostupnosti služieb. Občania vyžadujú, aby postupy pri vybavovaní občianskych záležitostí, záležitostí súvisiacich $\mathrm{s}$ ich podnikaním, sa prispôsobovali individuálnym požiadavkám občanov a služby verejnej správy boli pre občanov nepretržite dostupné.

\section{Strategický ciel' v oblasti informatizácie verejnej správy}

Strategickým ciel’om v oblasti informatizácie verejnej správy je:

- ul'ahčit' a rozšírit' účast' občanov na správe vecí verejných a ich styk s orgánmi štátnej správy a samosprávy prostredníctvom informatizácie služieb verejnej správy,

- ul'ahčit' styk podnikatel'skej sféry s orgánmi verejnej správy,

- zefektívnit' riadiace a administratívne procesy vo verejnej správe prechodom na digitálnu administratívu,

- pripravit' verejnú správu na plynulú integráciu do administratívnych štruktúr Európskej únie.

Na dosiahnutie tohto ciel'a je potrebné:

- zabezpečit’ tvorbu, aktualizáciu a integráciu relevantného digitálneho obsahu - informácií a služieb - občanom,

- zapojit' Slovensko do relevantných programov EÚ v tejto oblasti,

- zabezpečit' sprístupnenie verejných informácií a služieb nepretržite občanom a podnikatel'om,

- prehodnotit’ existujúce procesy verejnej správy z hl’adiska ich informatizácie,

\footnotetext{
* Dr. Ing. Margita Majerčáková, Katedra spojov, Fakulta prevádzky a ekonomiky dopravy a spojov, Žilinská univerzita v Žiline, Univerzitná 1, 01026 Žilina, Slovenská republika, tel.: +421415133126, fax: +421415655615 e-mail: Margita.Majercakova@fpedas.uniza.sk
} 
- vytvorit' a rozvíjat' integrovaný informačný systém verejnej správy,

- budovat' informačný systém verejnej správy využívaním nákladovo nenáročných riešení s využitím opakovaného nasadenia vytvoreného softvéru a zvýšit' finančnú efektívnost' tvorby informačného systému,

- vytvorit’ podmienky pre identifikáciu občanov v informačných systémoch a registroch verejnej správy a systémoch sociálnej a zdravotnej starostlivosti,

- zaviest' elektronický identifikačný preukaz totožnosti ako predpoklad pre využívanie integrovaných e-služieb.

Vláda SR schválila už v januári roku 2004 materiál „Stratégia informatizácie spoločnosti v podmienkach SR a Akčný plán“. V tomto materiále uložila vláda ministrovi dopravy, pôšt a telekomunikácií predložit’ na rokovanie vlády do 21. septembra 2004 „Návrh zákona o informačných systémoch verejnej správy“.

\section{Zákon o informačných systémoch verejnej správy}

Dňa 20. 5. 2006 bol uverejnený v Zbierke zákonov, zákon č. 275/2006 Z. z. o informačných systémoch verejnej správy a o zmene a doplnení niektorých zákonov. Zákon je účinný od 1. júna 2006.

Najdôležitejšie zmeny $\mathrm{v}$ zákone $\mathrm{v}$ porovnaní s predchádzajúcim právnym stavom sa týkajú týchto oblastí:

- ustanovuje právnu záväznost' vybraných štandardov pre informačné systémy verejnej správy,

- ustanovuje zodpovednost' za fungovanie ústredného portálu,

- upravuje vydávanie elektronických odpisov a výstupov z informačných systémov verejnej správy.

Zákon zavádza pojmový aparát, ktorým sa definuje informačný systém všeobecne a informačný systém verejnej správy, zavádza pojmy ako správca, prevádzkovatel' informačného systému a ústredný portál.

Pri návrhu zákona o informačnom systéme verejnej správy sa vychádzalo z toho, že informačný systém má predstavovat' funkčný celok zabezpečujúci ciel'avedomé systematické zhromažd’ovanie, spracovávanie, prenos, uchovávanie a likvidáciu údajov, získavanie, poskytovanie a sprístupňovanie informácií pomocou informačno-komunikačných technológií. Je dôležité uvedomit' si rozdiel medzi pojmami údaj a informácia. Zjednodušene možno povedat', že údaj je napr. postupnost' čísel, prípadne písmen, spracovaním ktorých vzniká informácia, ktorá dáva človeku akýsi zmysel. Podl'a dôvodovej správy, ktorá bola zverejnená k danému zákonu údajmi je to, čo môže byt' zachytené na nejakom nosiči, informáciami sú len vybrané údaje, o ktorých sa ich vlastník alebo poskytovatel' domnieva, že môžu u prijímatel'a zmenit' jeho stav poznania alebo uspokojit' jeho informačnú potrebu. V komplexnom ponímaní preto informačný systém zahŕňa nielen údajovú základňu, technické a programové prostriedky, ale aj procedúry ich spracovania a $\mathrm{v}$ konečnom dôsledku i pracovníkov, udržujúcich a využívajúcich tento systém.

$Z$ toho vyplýva, že informačný systém musí pokrývat’ tri roviny:

- technologické aspekty (informačné a komunikačné technológie)

- organizačné aspekty (procedúry a postupy) 
- l'udské zdroje (pracovníkov)

Principiálnymi požiadavkami na informačný systém verejnej správy sú:

- integrovatel'nost' (schopnost' vytvárat' vyššie celky)

- interoperabilita (schopnost' vymieňat' si a spoločne používat' údaje a informácie)

- bezpečnost' (odolnost' voči útoku zvonku, ochrana osobných údajov a pod.)

Zákon o IS verejnej správy preto:

- vymedzuje inštitucionálny rámec pre tento typ IS,

- definuje podmienky na využitie informačno-komunikačných technológií vo verejnej správe.

- Zakotvuje princípy jeho používania,

- Určuje pravidlá na spoločné využívanie údajov pri výkone verejnej správy.

Organizačne sa má IS verejnej správy javit' voči okoliu ako jeden systém zabezpečujúci súčinnost' orgánov verejnej správy, transparentnost' procesov, racionálnost' a efektívnost' systému. Z pohl'adu technologického treba zabezpečit', aby sa v určitom čase na každom mieste $\mathrm{v}$ rámci toho istého úseku verejnej správy dala dosiahnut' rovnaká kvalita a rozsah elektronického výkonu verejnej správy.

Verejná správa je činnost' vykonávaná orgánmi štátnej správy, samosprávy a verejnoprávnymi inštitúciami pri zabezpečovaní verejných úloh. Na Slovensku sa v súčasnosti uplatňuje model, v ktorom je štátna správa úplne oddelenou, samostatnou zložkou verejnej správy. V iných štátoch sa využíva model, v ktorom sú niektoré orgány verejnej správy súčasne orgánom štátnej správy aj orgánom samosprávy. Oba modely majú svoje výhody a nevýhody a ich výber súvisí $\mathrm{s}$ tradíciami, stavom rozvoja spoločnosti, stavom rozvoja technológií, atd'.

Štátnu správu možno rozdelit’ na:

a) Ústredná štátna správa, t.j. vláda a ministerstvá.

b) Miestna štátna správa, t.j. krajské a obvodné úrady,

c) Špecializovaná miestna štátna správa - na úsekoch cestnej dopravy a pozemných komunikácií, pozemkového a lesného hospodárstva, sociálnych vecí, rodiny a služieb zamestnanosti, ochrany životného prostredia, školstva atd'.

Samosprávu možno členit' na:

- miestna územná samospráva, t.j. mestá a obce,

- regionálna územná samospráva, t.j. vyššie územné celky.

Okrem toho sa ešte uvádza aj tzv. záujmová samospráva, predstavovaná súdnou samosprávou, verejnými korporáciami v oblasti poist'ovníctva, zdravotníctva, sociálnych vecí, životného prostredia, kultúry, školstva, telovýchovy.

Pôsobnosti ústredných orgánov štátnej správy sú ustanovené zákonom č. 575/2001 Z. z. o organizácii činnosti vlády a organizácii ústrednej štátnej správy v znení neskorších predpisov. Činnost' územnej samosprávy je vymedzená dvomi zákonmi:

- zákonom o samosprávnych krajoch č. 302/2001 Z. z. o samospráve vyšších územných celkov v znení neskorších predpisov, 
- zákonom o obecnom zriadení č. 369/1990 Z. z. v znení neskorších predpisov.

Vzhl'adom na komplexnost' problematiky sa zavádza prechodné obdobie dvoch rokov, počas ktorého treba existujúce informačné systémy verejnej správy dat' do súladu s novým zákonom. Zároveň sa ruši zákon č. 261/1995 Z. z. o štátnom informačnom systéme a upravuje sa zákon č. 211/2000 Z. z. o slobodnom prístupe k informáciám v znení neskorších predpisov tak, aby sa vytvorila možnost' poskytovat' informácie z orgánov verejnej správy cez internet, resp. na ústrednom portáli verejnej správy. Prijatý zákon si d’alej vyžaduje novelizáciu zákonov, týkajúcich sa využivania informačných a komunikačných technológií, a výmeny a spoločného využívania elektronických dokumentov jednotlivými subjektmi verejnej správy. Dalším krokom bude zrovnoprávnenie dokladov $\mathrm{v}$ elektronickej forme $\mathrm{s}$ ich listinnou podobou, čo umožní aplikovat' zásadu, že verejnej správe raz poskytnuté identifikačné údaje fyzických a právnických osôb sa nebudú opät' vyžadovat', ale iba sa požiada o odsúhlasenie ich platnosti. Rovnako bude treba zmenit' predpisy, upravujúce manuálne spracovanie údajov $\mathrm{s}$ ohl'adom na ich postupné nahradzovanie údajmi v elektronickej forme.

$\mathrm{V} \S 1$ je vymedzený predmet zákona, ktorým je vytváranie a prevádzka informačných systémov verejnej správy, prevádzka ústredného portálu a vydávanie elektronických odpisov z týchto systémov. Dôležité pritom je, že z pohl'adu zákona je samotný obsah elektronických dokumentov irelevantný, t.j. zákon nešpecifikuje podmienky práce s elektronickými dokumentmi podl'a toho, aké údaje, resp. informácie obsahujú. $Z$ jeho pôsobnosti sú však vyňaté systémy, majúce do činenia $\mathrm{s}$ obranou a bezpečnost'ou SR alebo $\mathrm{s}$ utajovanými skutočnost’ami. Tým, že sa $\mathrm{v}$ tomto paragrafe vyslovene spomína ústredný portál verejnej správy sa naznačuje, že v blízkej budúcnosti sa očakáva masívna internetizácia nielen verejnej správy, ale aj celej spoločnosti.

Na účely zákona bolo nevyhnutné definovat' niektoré nové pojmy a tiež prevziat' určité pojmy z iných, už platných zákonov (§ 2). Z charakteru definícií vyplýva, že ide o budovanie elektronického systému. $Z$ pohl'adu verejnej správy je dôležitá najmä definícia informačnej činnosti zahrnujúca získavanie, poskytovanie a sprístupňovanie údajov, ich zhromažd'ovanie, spracovávanie, prenos, ukladanie, archiváciu a likvidáciu. Aj ked'ide na prvý pohl'ad o tradičné činnosti vykonávané verejnou správou, použitie informačnokomunikačných technológií im dáva nový rozmer a vyžiada si vytvorenie celého radu vyhlášok a smerníc, upravujúcich jednotlivé postupy. Z praktického hl'adiska je dôležitý i fakt, že je samostatne definovaný správca informačného systému verejnej správy a jeho prevádzkovatel'. To vytvára možnost' zadat' prevádzkovanie systému externému dodávatel'ovi. Správcovi zostáva zodpovednost' za to, že prevádzka informačného systému je vykonávaná $\mathrm{v}$ súlade so zákonom pri dodržaní predpísaných štandardov.

V § 3 sú vymenované povinné osoby a ich povinnosti. Aby bola zabezpečená kompatibilita informačných systémov, sú medzi povinné osoby zahrnuté nielen orgány štátnej správy na všetkých úrovniach, ale aj orgány samosprávy a niektoré d’alšie inštitúcie, pracujúce $\mathrm{s}$ údajmi zo systémov verejnej správy (napr. Sociálna poist'ovňa). Jedným z kritických bodov zrejme bude práve koordinácia činnosti jednotlivých typov povinných osôb nielen pri prevádzke, ale hlavne pri rozvoji informačných systémov. Zákon okrem toho ukladá povinným osobám celý rad povinností idúcich nad rámec ich prevádzky, napríklad sprístupňovanie údajov, tvorbu metodík a zverejňovanie informácií o prevádzkovaných systémoch. Tieto činnosti budú musiet' vykonávat' tak, aby nimi nebola narušená bezpečnost' systémov, za ktorú tiež nesú zodpovednost'.

V zmysle zákona č. 678/2006 Z. z. ktorým sa mení a dopĺn̆a zákon č. 575/2001 Z. z. o organizácií činností vlády a organizácií ústrednej štátnej správy v znení neskorších predpisov a o zmene a doplnení niektorých zákonov, sa Ministerstvo financií SR k 1. 2. 2007 stalo 
ústredným orgánom štátnej správy pre oblast' informatizácie spoločnosti. Sekcia informatizácie spoločnosti plní úlohy ministerstva na úseku:

1. vypracúvania koncepcií informatizácie verejnej správy,

2. usmerňovania tvorby koncepcií rozvoja informačných systémov verejnej správy,

3. vydávania informačných štandardov,

4. sledovania stavu a hodnotenia rozvoja informačných systémov verejnej správy,

5. koordinácie budovania informačných systémov verejnej správy na národnej a medzinárodnej úrovni,

6. správy ústredného portálu verejnej správy,

7. riadenia a implementácie Operačného programu Informatizácia spoločnosti ako sprostredkovatel'ský orgán pod riadiacim orgánom.

Odbor stratégie informatizácie spoločnosti a medzinárodnej spolupráce plní najmä tieto úlohy

8. $\mathrm{v}$ spolupráci $\mathrm{s}$ ostatnými ústrednými orgánmi vypracúva a aktualizuje dokumenty strategického charakteru, týkajúce sa informatizácie spoločnosti,

9. koordinuje uskutočňovanie štátnej politiky informatizácie a stratégie informatizácie spoločnosti v rámci jednotlivých oblastí jej aktivít (e-health, e-culture, e-business, ....), analyzuje a hodnotí dosahované výsledky a navrhuje opatrenia na riešenie aktuálnych otázok,

10. koordinuje a zabezpečuje úlohy, ktoré pre SR vyplývajú z medzinárodných zmlúv $\mathrm{v}$ oblasti informatizácie, ako aj členstva v medzinárodných orgánoch a inštitúciách,

11. pri príprave strategických dokumentov využíva podnety a poznatky verejných inštitúcií, vedeckých inštitúcií, výskumných pracovísk a profesijných organizácií a spolupracuje $\mathrm{s}$ nimi,

12. $\mathrm{v}$ záležitostiach informatizácie spoločnosti zastupuje ministerstvo $\mathrm{v}$ príslušných poradných orgánoch vlády.

Odbor legislatívy, metodiky, štandardov a bezpečnosti informačných systémov plní najmä tieto úlohy

1. stará sa o náležitú právnu úpravu vytvárania podmienok aplikácie informačných a komunikačných technológií (legislatíva, metodika, štandardy),

2. stará sa o jednotnost' a záväznost' terminológie pre oblast' informatizácie, ako aj jej zosúladenie s terminológiou zavedenou v EÚ,

3. pripravuje a koordinuje spracovávanie návrhov zákonov a iných všeobecne záväzných právnych predpisov upravujúcich proces informatizácie,

4. pripravuje návrhy dátových štandardov,

5. zabezpečuje vydávanie a vyhlasovanie štandardov, vyhlášok a nariadení z oblasti aplikácie informačných a komunikačných technológií,

6. vypracúva stanoviská k vládnym návrhom zákonov z hl'adiska vplyvu na informatizáciu,

7. dbá na dodržiavanie zákonnosti pri aplikácii informačných a komunikačných technológií, analyzuje a hodnotí tento stav, 
8. analyzuje a hodnotí stav inklúzie právnej podpory aplikácie informačných a komunikačných technológií do právneho systému SR a navrhuje opatrenia na riešenie aktuálnych otázok,

9. pripravuje návrhy všeobecne záväzných predpisov a metodík týkajúcich sa bezpečnosti informačných systémov,

10. pripravuje návrhy technologických a bezpečnostných štandardov,

11. monitoruje, analyzuje a hodnotí stav bezpečnosti informačných systémov verejnej správy a tých informačných systémov, ktoré pracujú s osobnými údajmi a navrhuje opatrenia na riešenie aktuálnych otázok,

12. hodnotí koncepcie rozvoja informačných systémov verejnej správy $\mathrm{z}$ hl'adiska dodržiavania platného regulačného rámca a požiadaviek na ich bezpečnost',

13. zastupuje SR $\mathrm{v}$ európskych orgánoch a inštitúciách pre štandardy a informačnú bezpečnost',

14. v záležitostiach právneho rámca informatizácie spoločnosti zastupuje ministerstvo v Legislatívnej rade vlády,

15. riadi činnost' pracovných skupín pre prípravu návrhov zákonov, štandardov, metodík a informačnú bezpečnost'.

Odbor informatizácie verejnej správy plní najmä tieto úlohy

1. kontroluje dodržiavanie povinností, ktoré povinným osobám ustanovuje zákon č. 275/2006 Z.z. o informačných systémoch verejnej správy a o zmene a doplnení niektorých zákonov v znení zákona č. 678/2006 Z. z., navrhuje opatrenia na nápravu zistených nedostatkov a navrhuje sankcie za porušenie týchto povinností,

2. vypracúva a analyzuje Národnú koncepciu informatizácie verejnej správy, koordinuje jej realizáciu, monitoruje, analyzuje a hodnotí stav jej realizácie a navrhuje opatrenia na riešenie aktuálnych otázok,

3. usmerňuje tvorbu koncepcií rozvoja informačných systémov verejnej správy povinných osôb, schval'uje tieto koncepcie, monitoruje, analyzuje a hodnotí stav ich realizácie, navrhuje opatrenia na riešenie aktuálnych otázok,

4. v súčinnosti s odborom pre legislatívu, metodiku, štandardy a bezpečnost' informačných systémov hodnotí a schval'uje koncepcie rozvoja informačných systémov verejnej správy,

5. koordinuje budovanie informačných systémov verejnej správy na národnej a nadnárodnej úrovni najmä z hl'adiska ich interoperability, ako aj prepojitel'nosti na ústredný portál,

6. pripravuje informácie pre vládu o stave rozvoja informačných systémov verejnej správy,

7. vykonáva funkciu správcu ústredného portálu a zabezpečuje prepojenie informačných systémov s ústredným portálom,

8. vykonáva funkciu správcu metainformačného systému verejnej správy (informačný systém verejnej správy, ktorého obsahom sú technologické, administratívne a organizačné údaje o prevádzkovaných informačných systémoch verejnej správy),

9. vykonáva funkciu správcu informačných systémov verejnej správy nadrezortného a medzirezortného charakteru, 
10. monitoruje, analyzuje a hodnotí stav komunikačnej a technologickej infraštruktúry, poskytujúcej služby verejnej správe a verejnosti a navrhuje opatrenia na riešenie aktuálnych otázok,

11. koordinuje aktivity súvisiace s licencovaným SW pre verejnú správu,

12. koordinuje aktivity súvisiace s vytváraním a prevádzkovaním komunikačnej infraštruktúry verejnej správy,

13. v záležitostiach informatizácie verejnej správy zastupuje ministerstvo v Rade vlády pre verejnú správu.

Odbor riadenia Operačného programu Informatizácia spoločnosti sa člení na:

1. oddelenie metodicko-právne,

2. oddelenie monitorovania, hodnotenia a publicity Operačného programu Informatizácia spoločnosti. úlohy

Odbor riadenia Operačného programu informatizácia spoločnosti plní najmä tieto

a) oddelenie metodicko-právne

1. pripravuje podklady do Operačného programu informatizácia spoločnosti (d’alej len „OP IS), programového manuálu a súvisiacich dokumentov,

2. koordinuje a metodicky usmerňuje implementáciu OP IS,

3. metodicky usmerňuje prijímatel'ov formou vydávania príručiek, zabezpečovania školení a podávania metodických výkladov,

4. koordinuje vypracovávanie interného manuálu sprostredkovatel'ského orgánu pod riadiacim orgánom (SORO), vrátane audit trailov a rizikových analýz,

5. vypracováva schémy štátnej pomoci a realizuje dohl’ad nad ich uplatňovaním,

6. zabezpečuje posudzovanie a uzatváranie zmlúv o poskytnutí finančného príspevku,

7. realizuje výklad právnych noriem súvisiacich s implementáciou OP IS,

8. vybavuje st’ažností a podnety týkajúce sa implementácie OP IS,

9. metodicky usmerňuje prijímatel’ov v rámci procesu verejného obstarávania a realizuje dohl'ad nad jeho realizáciou,

10. eviduje usmernenia centrálneho koordinačného orgánu a certifikačného orgánu a zabezpečuje ich premietnutie do relevantných postupov a činností SORO,

11. zabezpečuje vzdelávanie zamestnancov v oblasti činností vykonávaných SORO,

b) oddelenie monitorovania, hodnotenia a publicity Operačného programu Informatizácia spoločnosti

1. zabezpečuje vypracovanie podkladov do výročných správ o implementácii OP IS,

2. zabezpečuje vyhlasovanie výziev na predkladanie žiadostí o poskytnutie finančného príspevku,

3. zabezpečuje organizáciu hodnotenia prijatých žiadostí o poskytnutie finančného príspevku,

4. overuje spolufinancovanie jednotlivých projektov zo zdrojov prijímatela, 
5. zabezpečuje spolufinancovania OP IS zo štátneho rozpočtu,

6. zabezpečuje prezentáciu, publicitu a informovanost' OP IS (vzt'ah s médiami, vypracovanie informatívnych podkladov a pod.),

7. vykonáva monitorovanie na úrovni OP IS,

8. zabezpečuje výkon hodnotenia na úrovni OP IS,

9. predkladá materiálov (správ, protokolov, záznamov) o výsledkoch následných finančných kontrol SORO vykonaných subjektami, okrem tých, ktoré vykonávajú kontrolu vzoriek operácií, certifikačnému orgánu do 5 pracovných dní od ich podpisu,

10. predkladá správy o výsledku vnútorného auditu SORO a správy o výsledku externého auditu SORO certifikačnému orgánu do 5 pracovných dní od ich podpisu,

11. predkladá opatrenia na nápravu nedostatkov a odstránenie príčin ich vzniku prijatých na základe následných finančných kontrol a systémových auditov vykonaných na riadiacom orgáne/sprostredkovatel'skom orgáne pod riadiacim orgánom a odpočty ich plnenia certifikačnému orgánu $\mathrm{v}$ termíne do 10 pracovných dní od ich prijatia a splnenia. tieto úlohy

Odbor implementácie Operačného programu Informatizácia spoločnosti plní najmä

1. prijíma a eviduje žiadosti prijímatel'ov o platbu,

2. vykonáva administratívnu kontrolu žiadostí prijímatel'ov o platbu, ktorá zahrňuje formálnu a vecnú kontrolu s ciel'om overenia reálnosti, oprávnenosti, správnosti, aktuálnosti a neprekrývania sa nárokovaných výdavkov, súladu s legislatívou SR a ES týkajúcou sa najmä štátnej pomoci, verejného obstarávania, rovností príležitostí, ochrany životného prostredia, publicity a pod.,

3. vykonáva kontrolu na mieste u prijímatel'a vrátane kontroly monitorovacích ukazovatel'ov (príprava, plánovanie, organizácia, analýza rizika),

4. sleduje čerpanie rozpočtu projektov a schval'uje ich prípadné zmeny,

5. schval'uje a predkladá žiadosti prijímatel'a o platbu vrátane prehlásenia o overení platobnej jednotke,

6. vypracováva a predkladá správy o zistenej nezrovnalosti certifikačnému orgánu najneskôr do 5 pracovných dní od jej zistenia,

7. vypracováva a predkladá odhad očakávaných výdavkov certifikačnému orgánu $\mathrm{k} 31$. marcu, 30. júnu, 30. septembru a 31. decembru príslušného roka $\mathrm{v}$ termíne do 10. pracovného dňa nasledujúceho mesiaca,

8. prijíma, eviduje a vyhodnocuje monitorovacie správy od prijímatel'ov,

9. agreguje monitorovacie ukazovatele,

10. zabezpečuje archiváciu dokumentácie.

\section{Ústrtedný portál verejnej správy}

Jedným z klúčových pojmov zákona o informačných systémoch verejnej správy je pojem ústredný portál verejnej správy, ktorý má byt' akousi vývesnou tabul'ou dostupnou nielen pre jednotlivé subjekty verejnej správy, ale aj pre širokú verejnost'. Portál je v súčasnosti už v prevádzke (http://portal.gov.sk/Portal/sk/Default.aspx) a poskytuje naozaj široké spektrum informácií ( $§ 5)$. Jeho význam bude rást' úmerne s tým, ako bude rást' 
internetizácia spoločnosti. Správcom ÚPVS je Ministerstvo dopravy, pôšt a telekomunikácií SR. Prevádzkovatel'om ÚPVS je Úrad vlády SR. Všetky predchádzajúce pokusy o integráciu rôznych informačných systémov zavádzaných vo verejnej správe stroskotali práve na nerešpektovaní štandardov. $\mathrm{V} \S 6$ síce nie sú detailne popísané povinné štandardy, ale zato tu sú vymenované oblasti, ktorých sa štandardy týkajú a požiadavky na ne. Ciel'om je zabezpečit' integrovatel'nost' a bezpečnost' systémov. Detaily upravuje výnos Ministerstva dopravy, pôšt a telekomunikácií Slovenskej republiky zo 14. júla 2006 č. 1706/M-2006 o štandardoch pre informačné systémy verejnej správy.

$\mathrm{V} \S 7$ je riešený pomerne komplikovaný problém vydávania odpisov a výstupov zo systému. Tradične sú používané a legislatívou upravené odpisy v papierovej forme. Tento zákon predpokladá, že zo systému bude možné vydávat' odpisy v elektronickej forme [2], pričom tieto odpisy budú $\mathrm{z}$ hl'adiska legislatívy rovnocenné s ich papierovými ekvivalentmi. To znamená, že takýto odpis bude musiet' zabezpečit' autenticitu a integritu dokumentu, čo sa dosiahne používaním elektronického podpisu a časovej pečiatky (podrobnosti pozri $\S 5$ zákona č. $215 / 2002$ Z. z. o elektronickom podpise a o zmene a doplnení niektorých zákonov v znení neskorších predpisov).

Na rozdiel od elektronického odpisu (ktorý má svoje výhody i nevýhody), výstupom zákon rozumie listinnú podobu elektronického odpisu, ktorá je opatrená osvedčovacou doložkou a má charakter verejnej listiny. Ide o postup, známy z doterajšej praxe, kedy sa papierové dokumenty overujú inštanciami na to určenými (napr. zákon č. 599/2001 Z. z. o osvedčovaní listín a podpisov na listinách obvodnými úradmi a obcami v znení neskorších predpisov).

$\mathrm{V} \S 8$ sú vymenované povinnosti povinnej osoby pri vydávaní odpisov a výstupov z informačného systému verejnej správy, a to ako z jeho verejnej, tak i neverejnej časti. $\mathrm{V}$ zásade sú aplikované štandardné postupy, vyžadujúce overenie totožnosti osoby, ktorá o odpis, resp. výstup žiada. Zodpovednost' za súlad údajov v odpise $\mathrm{s}$ údajmi v systéme nesie povinná osoba.

Ked’že elektronické dokumenty je vo všeobecnosti l'ahšie sfalšovat' ako papierové, budú zrejme povinné osoby používat' digitálne podpisy certifikované certifikačnými autoritami vyššej kategórie.

Ked’že internetizácia spoločnosti je len $\mathrm{v}$ začiatkoch, v zákone sa uvádza „Ak to umožňujú technické podmienky povinnej osoby podl'a $\S 7$ ods. 1, odošle osvedčujúcej osobe na požiadanie elektronický odpis podpísaný zaručeným elektronickým podpisom a opatrený časovou pečiatkou.“, čo je prakticky začiatok spolupráce verejnej správy napr. s notármi s využitím informačno-komunikačných technológií. Pri poskytovaní výstupov z neverejných častí informačných systémov, je povinná osoba zodpovedná za ich zabezpečenie voči útoku tretej osoby, t.j. pred krádežou a zneužitím.

Zákon prenáša vel'kú čast' zodpovednosti za pravost' elektronických dokumentov, získaných ako výstupy z informačných systémov verejnej správy na osvedčujúcu osobu, ktorou môže byt' napr. notár (§ 9). Osvedčujúca osoba predtým, ako dá $\mathrm{k}$ výstupu osvedčujúcu doložku, musí urobit' celý rad úkonov, súvisiacich najmä s overením pravosti digitálneho podpisu a jeho časovou platnost'ou, čo si vyžiada komunikáciu s certifikačnou autoritou.

Pri spracúvaní údajov a ich ochrane musí postupovat' najmä podl’a zákona č. 428/2002 Z. z. v znení neskorších predpisov, zákona č. 395/2002 Z. z. o archívoch a registratúrach a zákona o doplnení niektorých zákonov v znení zákona č. 515/2003 Z. z. 
V spoločných a prechodných, splnomocňujúcich a zrušovacích ustanoveniach je zaujímavá 2 ročná prechodná doba na uvedenie už existujúcich systémov do súladu s týmto zákonom.

To je pomerne krátka doba, ak zoberieme do úvahy objemy dát, ktoré zrejme bude treba konvertovat' do nových formátov. Splnomocňujúce ustanovenie ukladá ministerstvu povinnost' podrobnejšie definovat' štandardy, čo sa už medzitým udialo (výnos Ministerstva dopravy, pôšt a telekomunikácií Slovenskej republiky zo 14. júla 2006 č. 1706/M-2006 o štandardoch pre informačné systémy verejnej správy).

Zákon venuje osobitnú pozornost' ústrednému portálu ako kl'účovému informačnému systému, ktorý plní z pohl'adu užívatel'a integračnú funkciu prístupu k službám verejnej správy z jedného miesta. Ústredný portál verejnej správy je jedným zo základných pilierov eGovernmentu v Slovenskej republike. Je virtuálnym prostredím, ktoré v jednom bode umožní sprístupnit' všetky dostupné elektronické služby a aktuálne informačné zdroje verejnej správy pre občana a podnikatel'a na internete. Výsledkom budovania a sprístupnenia takéhoto portálu je:

- ul'ahčenie komunikácie s úradmi,

- zlepšenie a urýchlenie služieb,

- transparentnost' procesov,

- úspora nákladov pre občana aj podnikatel’a,

- sprístupnenie služieb verejnej správy v SR v jednom bode,

- $\quad$ sprístupnenie bezpečnej komunikácie a aktualizovaných informácí́.

Vytvorenie takéhoto portálu je dlhodobý a vo svojej podstate nikdy nekončiaci projekt, ktorý sa bude rozvíjat' d'alej po technologickej a obsahovej stránke na základe požiadaviek občanov a rezortov.

Ústredný portál verejnej správy (ÚPVS) zabezpečuje centrálny a jednotný prístup k informačným zdrojom a službám verejnej správy. Informácie (rady, návody, popisy), ktoré návštevník hl’adá, sú v súčasnosti mnohokrát súčast'ou informačných serverov jednotlivých rezortov. Ciel'om portálu je tieto informácie a služby zintegrovat' a prehl'adnou a prístupnou formou poskytovat' používatel'ovi.

Medzi najvýznamnejšie úlohy portálu patrí nasmerovanie používatel’a na využitie konkrétnej elektronickej služby verejnej správy s využitím relevantných informačných zdrojov .

Obsah ÚPVS zahŕňa digitálny obsah vo forme podporných informácií pre využitie služby a samotné poskytovanie elektronických služieb [1]. Koncept obsahu ÚPVS sa riadi nasledujúcimi princípmi:

- organizácia informácií a služieb podl'a životnej situácie - v súčasnom „informačnom pretlaku“ býva často t’ažké práve získanie hladanej a potrebnej informácie. Z tohto dôvodu sú služby na ÚPVS logicky členené podl'a konceptu „životných situácií.“ Tento koncept umožňuje pristupovat' $\mathrm{k}$ požadovaným informačným zdrojom, ako aj elektronickým službám štruktúrovane, podl'a skutočných požiadaviek používatel'a a cielene filtrovat' rozsiahly obsah ÚPVS. Štrukturalizácia obsahu ÚPVS je jedným z rozhodujúcich prínosov ÚPVS vzhl'adom $\mathrm{k}$ distribuovaným zdrojom na stránkach jednotlivých pripojených subjektov. 
- rozdelenie informačného obsahu podl'a typu subjektu - informačný obsah je v koncepte životných situácií členený podl'a ciel’ovej skupiny. Tou môžu byt' jednak občania, podnikatel'ské subjekty, či zahraničné osoby žijúce v SR. Súčasne je obsah členený podl'a iných charakteristík ciel'ovej skupiny, ako napr. špeciálny obsah a forma jeho prezentácie pre rôznym spôsobom postihnuté osoby.

- virtuálna centralizácia - z hl'adiska používatel'ov služieb ÚPVS predstavuje portál centralizované riešenie, kde sú z jedného miesta dostupné všetky informácie a logicky členené elektronické služby prístupné jednotným spôsobom. Centralizácia však nie je realizovaná presunom služieb na ÚPVS, jedná sa o virtuálne centralizovaný systém, ktorý predstavuje integračnú platformu pre všetky d’alšie služby - informačné zdroje a systémy implementujúce jednotlivé procesy. Vládny portál aj s distribuovanou štruktúrou, sa však používatel'ovi javí ako centralizovaný systém s jednotnou logikou a štruktúrou.

Ústredný portál verejnej správy [3] je definovaný ako informačný systém verejnej správy na poskytovanie služieb a informácií verejnosti prostredníctvom spoločného prístupového miesta $v$ sieti internet podl'a zákona č. 275/2006 Z. z. o informačných systémoch verejnej správy. Správcom ÚPVS je Ministerstvo dopravy, pôšt a telekomunikácií SR. Prevádzkovatel'om ÚPVS je Úrad vlády SR.

Vytvorenie Ústredného portálu verejnej správy bolo spolufinancované Európskou úniou $\mathrm{z}$ prostriedkov Phare $\mathrm{v}$ rámci projektu "Transparency in Functioning of State administration and Public Self-administration".

\section{Záver}

Limitujúcim faktorom úspechu každej technológie a nástroja je l’udský faktor. Ak nie je nástroj dokonalý a prijatý povinným subjektom, pre ktorý je určený, zostávajú potencionálne prínosy nevyužité. Za týmto účelom sa zavádzajú štandardy, ktorými sa zabezpečí najmä bezpečnost' a integrovatel'nost' informačných systémov verejnej správy.Zvyšujúce sa nároky užívatel’ov na používanie internetu vedú $\mathrm{k}$ neustálemu napredovaniu nových technológií, ktoré nahrádzajú staršie technológie s nižšími prenosovými rýchlost’ami. Internetové služby sa stávajú čoraz viac dostupnými. Problémom však zostáva výber vhodnej použitej technológie a vol'ba poskytovatel'a, existuje totiž viacero technológií a množstvo poskytovatel'ov. Nie je jednoduché sa preto správne rozhodnút'.

\section{Literatúra}

[1] VACULÍK, J.: Telematické služby - Žilina : Žilinská univerzita v EDIS, 1998. - 127 s., ISBN 80-7100-530-4.

[2] MADLEŇÁK, R. Elektronický obchod. Žilina: Žilinská univerzita, 2004, 160 s. ISBN 80-8070-192-X.

[3] http://www.portal.gov.sk/Portal/sk/Default.aspx [online]. [s.a.]. [Cit. 2007-06-02].

\section{Grantová podpora}

I14-07-140 Príležitosti a hrozby e-mailovej komunikácie

VEGA 1/2548/05 Kvalita služieb vnímaná zákazníkom 